\title{
Prediction methodology for potential damage from misuse of agricultural lands
}

\author{
Kirill Zhichkin ${ }^{1}$, Vladimir Nosov ${ }^{2,3,}$, Lyudmila Zhichkina ${ }^{4}$, Sergei Tkachev ${ }^{5}$, and Liudmila Voloshchuk $^{5}$ \\ ${ }^{1}$ Samara State Agrarian University, Department of Economic Theory and Economics of AIC, 446442 Kinel, Russia \\ ${ }^{2}$ K.G. Razumovsky Moscow State University of Technologies and Management, Department of Economics and Management, 109004 \\ Moscow, Russia \\ ${ }^{3}$ Academy of the Investigative Committee of the Russian Federation, Department of Humanitarian and Socio-Economic Disciplines, \\ 125080 Moscow, Russia \\ ${ }^{4}$ Samara State Agrarian University, Department of Land Management, Soil Science and Agrochemistry, 446442 Kinel, Russia \\ ${ }^{5}$ Saratov State Vavilov Agrarian University, Department of Economic Cybernetics, 410012 Saratov, Russia
}

\begin{abstract}
The article is devoted to development of prediction methodology for potential damage from misuse of agricultural lands such as accommodation of oil and gas industry facilities, transport, infrastructure complexes, and emergency management. The purpose of the research is to propose a methodology for determination of potential damage to territory from misuse of agricultural lands. In order to do this, the following objectives need to be achieved: - group the sources of damage from agricultural lands misuse based on empirical evidence; - determine and classify the main types of damage and their periods; - develop the methodology and mathematical apparatus for calculation and prediction of damage extent on the "municipal district-region" level; - predict the losses from agricultural lands misuse in accordance with conditions of the Samara region. The proposed methodology allows one to more accurately assess the damage to large territories (district, region, country), which is essential to the work of administrative bodies. For calculation purposes, all cases of agricultural lands misuse are divided into four categories, each of which has its features of damage development. The obtained methodology was tested in the Samara region, where annually from 2.5 to 4.0 thousand ha of agricultural lands are used for other purposes than intended. Note that more than $20 \%$ of this number is removed from use for a long period of time (for more than 10 years). Oil spills account for $2.3-4.0 \%$ of land misuse. In 2021 the resulting damage could amount to 1.9 billion rubles.
\end{abstract}

\section{Introduction}

Food security governance is one of the core state functions in the Russian Federation. Effective use of agricultural lands is a condition for effective fulfillment of this mission. Despite large amounts of land (1712.5 $\mathrm{mln}$ ha), only $11.5 \%$ of it (197.7 $\mathrm{mln}$ ha) is used for agriculture. The additional factor that determines the importance of this category of lands is their low competitiveness compared to the other categories, therefore, they require special protection $[1,2]$.

The purpose of the research is to develop a methodology for determination of potential damage to territory from misuse of agricultural lands. In order to do this, the following objectives need to be achieved:

- group the sources of damage from agricultural lands misuse based on empirical evidence;

- determine and classify the main types of damage and their periods;

- develop the methodology and mathematical apparatus for damage extent calculation and prediction on the "municipal district-region" level;
- predict the losses from agricultural lands misuse in accordance with conditions of the Samara region.

\section{Methods and materials}

The object of study is economic relationships arising in the process of agricultural lands misuse. Abstract-logical method, situation and system analysis, methods of statistical analysis, and expert evaluation method were used in the study to analyze the features of damage development in cases when agricultural production activities on specialized lands are substituted with other types of use (construction, oil and gas recovery, etc.).

\section{Results and Discussion}

Currently most researchers consider damage to agricultural lands in terms of a separate project, land plot $[3,4,5]$. Situations often arise where administrative bodies must assess and predict losses in districts, regions, countries. In this case, the assessment is often based on the experts opinion and is largely voluntaristic

\footnotetext{
${ }^{*}$ Corresponding author: novla@) list.ru
} 
$[6,7]$. In order to increase the credibility of prediction, we proposed to use the methodology described below.

For aggregate estimation of potential damage from agricultural lands misuse in the "municipal districtregion" system, the following actions should be implemented:

1. Statistical data on agricultural lands misuse should be collected. In the Samara region the Federal State Budgetary Institution "Samara Reference Center of Rosselkhoznadzor" possesses this information.

In accordance with the above classification, all areas should be grouped by three types (arable lands, pastures and hayfields), and into three categories (creation of stationary objects for long-term operation (wells); scheduled pipeline repair, replacement or elimination works; and works related to the emergencies management) [8].

Table 1. Results of damage calculation in 2015-2019 on the Samara region territory.

\begin{tabular}{|c|c|c|c|c|c|}
\hline \multirow{2}{*}{ Indicator } & \multicolumn{5}{|c|}{ Amount of damage, mln rubles } \\
\cline { 2 - 6 } & $\mathbf{2 0 1 5}$ & $\mathbf{2 0 1 6}$ & $\mathbf{2 0 1 7}$ & $\mathbf{2 0 1 8}$ & $\mathbf{2 0 1 9}$ \\
\hline $\begin{array}{c}\text { Damage } \\
\text { from land } \\
\text { occupation } \\
\text { during } \\
\text { previous } \\
\text { years }\end{array}$ & 34.5 & 52.3 & 64.4 & 39.2 & 73.8 \\
\hline $\begin{array}{c}\text { Damage } \\
\text { from land } \\
\text { occupation } \\
\text { during } \\
\text { current year }\end{array}$ & 0.9 & 2.5 & 7.9 & 10.4 & 13.0 \\
\hline $\begin{array}{c}\text { Damage } \\
\text { from misuse } \\
\text { of lands } \\
\text { during } \\
\text { scheduled } \\
\text { repair works }\end{array}$ & 185.7 & 307.0 & 1072.6 & 703.4 & 1326.6 \\
\hline $\begin{array}{c}\text { Damage } \\
\text { from land } \\
\text { occupation } \\
\text { during the } \\
\text { emergency } \\
\text { management }\end{array}$ & 8.4 & 36.7 & 27.5 & 37.9 & 85.1 \\
\hline \begin{tabular}{c} 
Total \\
\hline
\end{tabular} & 229.5 & 398.6 & 1172.4 & 791.0 & 1498.5 \\
\hline
\end{tabular}

2. The obtained data should be linked with the damage time structure (with the period (first, second, and last years), type and amount (loss of profit, actual costs, remediation costs) of possible damage). Obtained agricultural lands areas are divided into four groups based on the type of damage: damage from land occupation during previous years, damage from land occupation during current year, damage from misuse of lands during scheduled repair works, damage from land occupation during the emergency management [9].

As part of the study, works were distributed in 20152019 in municipal districts of the region. Based on this information, we calculated the damage to land users from misuse of agricultural lands and presented the results in Table 1.

3. Damage from land occupation during previous years can be estimated only based on the loss of profit.
In this case its amount can be estimated as the average value of agricultural lands productivity of the considered territory. For this, the cost of crop products should be divided by crop acreage. Data for calculation can be obtained from the territorial body of Federal State Statistics Service in the Samara region. The resulting value is multiplied by lands used for non-agricultural purposes.

$$
S_{p i}=C_{y n i}=\bar{Y} * S_{n s}
$$

where $\bar{Y}$ is crop products per 1 ha in actual prices for the period in considered municipal district, rubles; $S_{n s}$ is area of agricultural lands used for non-agricultural purposes in the municipal district, ha; $C_{y n i}$. is loss of profit, rubles.

4. Damage from land occupation during current year is drawn from the amount of damage from the loss of profit, which can be estimated as described in paragraph 3 , and actual costs of crop production on territories occupied for creation of non-agricultural objects. While the exact costs are impossible to estimate, the guide value can be calculated based on the average cost of crop production, harvesting costs are not included. The averaged value of actual damage from land occupation during different periods of time can be calculated by dividing the guide value in half. Data on average crop growing costs are collected by the Ministry of Agriculture and Food of the Samara region.

$$
S_{t i}=C_{y n i}+C_{\varphi i}=C_{y n i}+\left(C_{p}-C_{H}\right) \cdot S_{n s} / 2
$$

where $C_{\varphi i}$ is actual costs before the temporal occupation of agricultural lands, rubles; $C_{p}$ is total costs of crop production, rubles/ha; $C_{H}$ is harvesting costs, rubles/ha.

5. Damage from misuse of lands during scheduled repair works differs in that the works are prearranged, which means that there is a possibility to avoid actual costs. The damage is drawn from loss of profit sums and land remediation costs. Land remediation costs are generalized and can be determined based on the estimated cost [10], which can be corrected with the application of the estimated cost change index at the time of calculation. The obtained value is multiplied by area of agricultural lands belonging to this group.

$$
S_{p l i}=C_{y n i}+C_{n i}=C_{y n i}+E_{c c} \cdot K_{c} \cdot S_{n s}
$$

where $E_{c c}$ is the calculated single average cost of restoration of 1 ha of arable lands, rubles/ha; $C_{n i}$ is costs of recultivation of occupied lands, rubles; $K_{c}$ is the estimated cost change index at the time of calculation.

6. Losses due to damage from land occupation during the emergency management can be calculated based on actual costs, loss of profit, emergency recovery costs and land recultivation. Identification of emergency recovery costs is related to the fact that, according to the section 3 , their value is greater than the one of scheduled agricultural lands recultivation. 


$$
\begin{aligned}
& S_{c h i}=C_{y n i}+C_{\varphi i}+C_{n i}+C_{E R}= \\
& =C_{y n i}+C_{\varphi i}+E_{c c} \cdot K_{C} \cdot S_{n s} \cdot\left(1+K_{E R}\right)
\end{aligned}
$$

where $C_{E R}$ is emergency recovery costs, rubles/ha; $K_{E R}$ is the increasing coefficient, which reflects an increase in costs of land recultivation during the emergency recovery, rubles/ha.

7. We statistically processed the data obtained on 4 groups. In this case we propose to use the regression analysis and use time as an independent variable. There is also a need to estimate the correlation ratio. Only if the approximation coefficient $\left(\mathrm{R}^{2}\right)$ is more than 0.7 , the relationships can be used for prediction of researched indicators values [11]. If historical data are available for only 5-6 years, this approach can be implemented in order to develop a prediction for 1-2 years ahead. A longer pre-prediction period is not desirable.

Table 2. Prediction functions for damage determination (by types).

\begin{tabular}{|c|c|c|}
\hline Indicator & Function & $\mathbf{R}^{\mathbf{2}}$ \\
\hline $\begin{array}{c}\text { Damage from land occupation } \\
\text { during previous years }\end{array}$ & $y=6.55 x+33.19$ & 0.6916 \\
\hline $\begin{array}{c}\text { Damage from misuse of lands } \\
\text { during scheduled repair works }\end{array}$ & $y=3.21 x-2.69$ & 0.9738 \\
\hline $\begin{array}{c}\text { Damage from land occupation } \\
\text { during current year }\end{array}$ & $y=267.82 x-$ & 0.7561 \\
\hline $\begin{array}{c}\text { Damage from land occupation } \\
\text { during the emergency } \\
\text { management }\end{array}$ & $y=15.46 x-7.26$ & 0.7469 \\
\hline
\end{tabular}

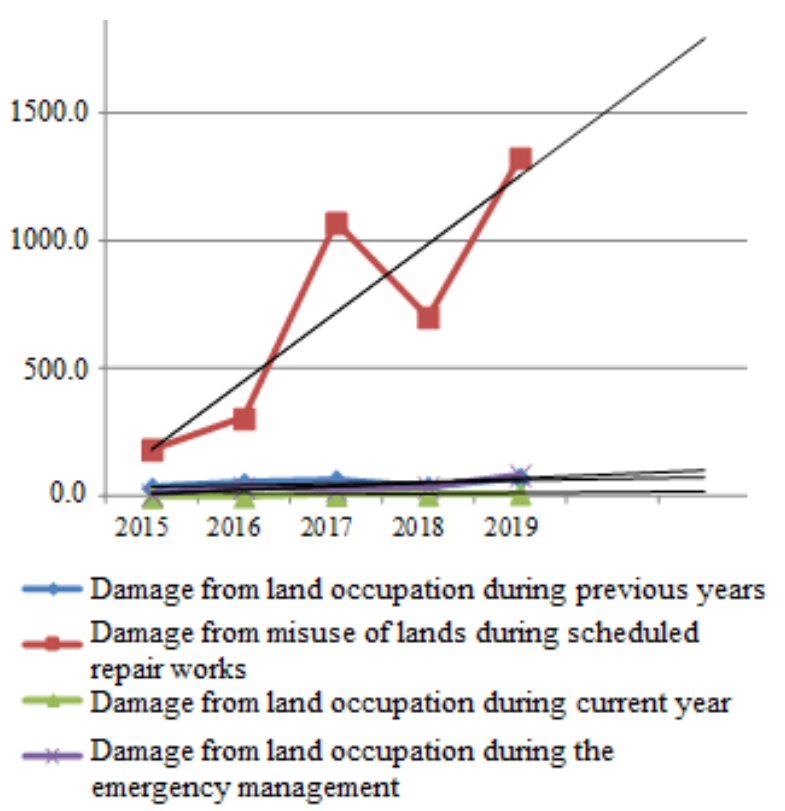

Fig. 1. Prediction of amount of damage from misuse of agricultural lands.

Based on the obtained data, we made a prognosis using the MS Excel "Data analysis" package. For every type of damage a trend equation was determined. Table 2 and Figure 1 illustrate these equations.

As a result of prognosis, the following data for 2020 and 2021 were obtained and presented in Table 3.
Table 3. Prediction of development of damage from misuse of agricultural lands in 2020 and 2021 in the Samara region.

\begin{tabular}{|c|c|c|c|c|}
\hline \multirow{2}{*}{ Indicator } & \multicolumn{4}{|c|}{ Estimated damage amount, mln rubles } \\
\cline { 2 - 5 } & $\mathbf{2 0 1 8}$ & $\mathbf{2 0 1 9}$ & $\mathbf{2 0 2 0}$ & $\mathbf{2 0 2 1}$ \\
\hline $\begin{array}{c}\text { Damage from } \\
\text { land } \\
\text { occupation } \\
\text { during } \\
\text { previous years }\end{array}$ & 59.39 & 65.94 & 72.49 & 79.04 \\
\hline $\begin{array}{c}\text { Damage from } \\
\text { land } \\
\text { occupation } \\
\text { during current } \\
\text { year }\end{array}$ & 10.15 & 13.36 & 16.57 & 19.78 \\
\hline $\begin{array}{c}\text { Damage from } \\
\text { misuse of } \\
\text { lands during } \\
\text { scheduled } \\
\text { repair works }\end{array}$ & 986.88 & 1254.7 & 1522.5 & 1790.3 \\
\hline $\begin{array}{c}\text { Damage from } \\
\text { land } \\
\text { occupation } \\
\text { during the } \\
\text { emergency } \\
\text { management }\end{array}$ & 54.58 & 70.04 & 85.5 & 100.96 \\
\hline Total & 1111.0 & 1404.0 & 1697.1 & 1990.1 \\
\hline
\end{tabular}

The prognosis shows that if the trend is maintained (which is highly likely), the amount of damage will increase and will reach 1.99 billion rubles by 2021 .

\section{Conclusion}

The assessment of damage from misuse of agricultural lands is an important task for the authorities as it lies at the root of adoption of important strategic decisions in governance. Therefore, the accuracy of obtained result ensures the appropriateness and effectiveness of undertaken actions.

The proposed methodology allows one to adopt the approach that ensures more accurate calculations though selection of groups of actions with similar damage parameters.

The obtained methodology was tested in the Samara region, where annually from 2.5 to 4.0 thousand ha of agricultural lands are used for other purposes than intended. It should also be noted that more than $20 \%$ of this number is removed from use for a long period of time (for more than 10 years). Oil spills account for 2.3$4.0 \%$ of land misuse. In 2021 the resulting damage could amount to 1.9 billion rubles.

\section{References}

[1] D. Halmova, A. Feher, J. Cent. Eur. Agric., 15, 245-253 (2014).

[2] K. Zhichkin, V. Nosov, L. Zhichkina, Zh. Dibrova, T. Cherepova, IOP Conf. Ser. Earth Environ. Sci. 315, 022023 (2019).

[3] M. Carroll, Considerations for Transferring Agricultural Land to Solar Panel Energy Production, NC SU (2018) [Electronic resource]. Available at: https://craven.ces.ncsu.edu/ 
considerations-for-transferring-agricultural-landto-solar-panel-energy-production.

[4] M.Y.P. Fung, T.M. Macyk, Reclamation of drastically disturbed lands, ASA, 755-774 (2000).

[5] T. Williams, Can.: Lib. Parl., Pipelines: Environmental Considerations, 7 (2012).

[6] E. Potter, A. Vega, Oil Pollution: Issues, Impacts and Outcomes, 1-142 (2018).

[7] D. Tilman, Ecology, 77, 350-363 (1996).

[6] K. Zhichkin, V. Nosov, L. Zhichkina, V. Zhenzebir, O. Sagina, IOP Conf. Ser. Earth Environ. Sci., 421, 022066 (2020).

[7] D.V. Mashkin, T.V. Izvekova, A.A. Gushchin, V.I. Grinevich, Izv. Vyssh. Uchebn. Zaved. Khim. Khim. Tekhnol., 60, 94-99 (2017).

[8] A. Poltarykhin, V. Nosov, L. Poletaeva, V. Avdotin, V. Grishin, M. Babakisiyev, Problems of the ecological system in Russia and directions for their solution based on economic and social development programs, J. Environ. Manag. Tour., 10, 508-514 (2019).

[9] I. Sivkov, V. Parfenov, S. Aleksandrov, A. Nikiforov, Int. Multidiscip. Sci. Geoconf., SGEM, 2, 665-672 (2016) 